\title{
RESEARCH
}

Open Access

\section{On the biocontrol by Trichoderma afroharzianum against Fusarium culmorum responsible of fusarium head blight and crown rot of wheat in Algeria}

Hamza Bouanaka ${ }^{1}$, Ines Bellil ${ }^{1 *}$ (D), Wahiba Harrat ${ }^{2}$, Saoussene Boussaha ${ }^{2}$, Abdelkader Benbelkacem $^{2}$ and Douadi Khelifi' ${ }^{1,3}$

\begin{abstract}
Background: Durum wheat (Triticum durum Desf.) is one of the most important cereals in the world. Unfortunately, the wheat plant is a target of several species of the genus Fusarium. This genus causes two serious diseases: fusarium crown rot (FCR) and fusarium head blight (FHB). The search for new indigenous strains of Trichoderma with a high potential for biocontrol against these two diseases was the purpose of this study.

Results: Biocontrol potential of 15 isolates of Trichoderma (T1 to T15), isolated from different rhizosphere soils and Algerian ecosystems, was evaluated against 4 strains of Fusarium culmorum (FC11, FC2, FC4, and FC20); the main causative agent of FCR and FHB. The efficacy of biological control by Trichoderma spp., evaluated by in vitro tests (direct and indirect confrontation), was confirmed by in vivo bioassays. The in vitro results showed a significant inhibition of mycelial growth of $F$. culmorum species than the control. The highest percentages of inhibition were obtained by T9, T12, and T14 isolates causing a maximum inhibition percentage of 81.81, 77.27, and 80.68\%, respectively. T14 was selected for biocontrol in in vivo testing. A tube and pot experiments for FCR against $F$. culmorum showed that T14 decreased the disease severity with 50 and $63.63 \%$ reduction, respectively. FHB infection was significantly reduced by T14 in all durum wheat cultivars tested, where \%AUDPC (area under the disease progress curve) reduction was 49.77, 43.43, 48.25, and 74.60\% for Simeto, Waha, Bousselem, and Setifis genotypes, respectively. Yields also increased significantly for almost all cultivars. The antagonistic T14 was characterized based on molecular tools, using translation elongation factor1-alpha (TEF1-a) and internal transcribed spacers rDNA (ITS1). The results identified T14 as T. afroharzianum with accession numbers attributed by NCBI GenBank as MW171248 and MW159753.
\end{abstract}

Conclusions: Trichoderma afroharzianum, evaluated for the first time in Algeria as biocontrol agent, is a promising biocontrol approach against FCR and FHB.

Keywords: Triticum durum, Trichoderma afroharzianum, Fusarium, Biocontrol, Pathogenicity, Algeria

\footnotetext{
* Correspondence: bines07@yahoo.fr

'Laboratoire de Génétique Biochimie et Biotechnologies Végétales, Faculté des Sciences de la Nature et de la Vie, Université Frères Mentouri

Constantine 1, 25000 Constantine, Algeria

Full list of author information is available at the end of the article
}

\section{Springer Open}

(0) The Author(s). 2021 Open Access This article is licensed under a Creative Commons Attribution 4.0 International License, which permits use, sharing, adaptation, distribution and reproduction in any medium or format, as long as you give appropriate credit to the original author(s) and the source, provide a link to the Creative Commons licence, and indicate if changes were made. The images or other third party material in this article are included in the article's Creative Commons licence, unless indicated otherwise in a credit line to the material. If material is not included in the article's Creative Commons licence and your intended use is not permitted by statutory regulation or exceeds the permitted use, you will need to obtain permission directly from the copyright holder. To view a copy of this licence, visit http://creativecommons.org/licenses/by/4.0/. 


\section{Background}

Durum wheat (Triticum durum Desf.) is the main staple food crop in Algeria, where huge quantities are grown and traditionally consumed in the form of semolina and bread. However, it is affected by several abiotic and biotic stresses. Among the latter, fusarium crown rot (FCR) and fusarium head blight (FHB), which are considered two serious fungal diseases of wheat in the world, leading to significant yield losses and reduced market prices due to the poor quality of infected grains (Moya-Elizondo 2013). FCR in wheat causes the invasion of crown and root tissues by Fusarium spp. mycelia, which induces their decay and reduces the efficiency of nutrient and water absorption, while FHB is manifested by the bleaching of spikelets (Xu and Nicholson 2009).

Some Fusarium species are among the dangerous cereal pathogens with its secondary metabolites such as deoxynivalenol (DON), zearalenone (ZEN), and fumoni$\sin \mathrm{B} 1$, that are among the five most important mycotoxins (Mielniczuk and Skwaryło-Bednarz 2020). Investigations carried out revealed that strains of F. culmorum was the dominant and most aggressive species on wheat seedlings associated with FCR and FHB in Algeria (Abdallah-Nekache et al. 2019). In addition to yield losses, F. culmorum causes the accumulation of various mycotoxins such as 3-acetyl deoxynivalenol (3ADON) or nivalenol (NIV) (Laraba et al. 2017).

There are no effective and consistent control measures against Fusarium. In addition, resistance in commercial cultivars is only partial. Disease control is based primarily on the use of fungicides, and crop techniques such as rotation to reduce the occurrence of the disease (Wegulo et al. 2015). The chemical treatments pose a potential risk to human and animal health and increase environmental pollution, such as altering the beneficial functions of microorganisms living in the soil and rhizosphere ecosystem, and their effectiveness differs according to the fungal species concerned. Recently, biological control agents have been accepted as an ecological alternative (Akrami and Yousefi 2015). It is one of the most promising tools to maintain the current level of agricultural production and to control Fusarium spp. (Wegulo et al. 2015; Tian et al. 2016).

Trichoderma species have emerged as the most powerful bioprotectors for the management of a number of plant diseases due to their broad-spectrum action (Mukhopadhyay 2005). Trichoderma spp., is a cosmopolitan fungus common in different biotopes. It involves different types of interaction with other microorganisms in the rhizosphere. Some Trichoderma spp. are opportunistic and show a parasitic lifestyle such as T. harzianum, T. longibrachiatum, and T. atroviride, which live in the soil, without adverse effects on the environment and non-toxic to human health (Ghazalibiglar et al. 2016). The ability to produce volatile and non-volatile fungitoxic substances vary from one species to another and even between strains of the same species. The production of antibiotics is the most important antagonistic capacity. However, mycoparasitism has been proposed as the primary antagonistic mechanism exhibited by Trichoderma spp. (Zeilinger et al. 2016).

In vitro methods are considered among the easiest and fastest screening techniques, by using double culture plates, commonly used to select Trichoderma strains with potential antagonistic effects and omitting those with no biological activity (Matarese et al. 2011). Trichoderma is easily obtained by the multi-tube dilution technique due to its chlamydospore formation and colonization of organic substrates (Khandelwal et al. 2012). Conidia have been commonly used for biological control and conidial biomass can be grown by the submerged culture method or on solid substrate (Harman and Kubicek 1998).

The objectives of the present investigation were (i) isolation of Trichoderma spp. and in vitro evaluation of the antagonistic power against four strains of F. culmorum, the causal agent of FCR and FHB in Algeria; (ii) evaluation of Trichoderma as a biocontrol agent against FCR by two in vivo tests in the growth chamber; (iii) evaluation of the biocontrol potential against FHB in the pot test in the greenhouse; and (iv) identification of the most antagonistic species by molecular characterization.

\section{Methods \\ Fungal material}

For the isolation of the antagonistic agents, 68 soil samples were collected at a depth of 20 to $30 \mathrm{~cm}$, in different provinces of Algeria (Table 1). They were collected at random from the rhizosphere of different wheat fields and also from soils of different ecosystems. They were placed in sterile plastic bags. Fifteen isolates of Trichoderma (Table 1) were isolated using the suspensiondilution method (flat dilutions) (Davet and Rouxel 1997); they were purified by monospore culture, then stored as mycelium discs on agar in eppendorf tubes in $20 \%$ glycerol at $-80{ }^{\circ} \mathrm{C}$ (Siou et al. 2013).

Four Fusarium culmorum strains coded (FC11, FC2, FC4, and FC20) were submitted to GenBank (NCBI) under accessions numbers MW151664, MW165423, MW165434, and MW165435, respectively, were used. They are characterized by their aggressiveness among a collection of phytopathogenic wheat Fusarium species belonging to the fungal library of our laboratory. Fusarium strains were used as a pathogen in in vitro test. For in vivo tests, only FC2 was used.

\section{Plant material}

Durum wheat cultivar Simeto, known for its susceptibility to Fusarium, was used for both in vivo tests in 
Table 1 Code of Trichoderma isolates, with the soil type, region, and province of their isolation

\begin{tabular}{llll}
\hline Trichoderma isolate code & Type of soil & Town and region & Provinces \\
\hline T1 & Sand & Tahir plage bazoul & Jijel \\
T2 & Mountainous soil & El akhdaria & Bouira \\
T3 & Mountainous soil & El akhdaria & El meghaier \\
T4 & Agricultural sand (potato) & Oued athmania & Oued Souf \\
T5 & Forest soil & Barrage grouz & Mila \\
T6 & Agricultural soil & El harrouch & Skikda \\
T7 & Agricultural soil & El harrouch & Skikda \\
T8 & Mountainous soil & Ain zouit & Skikda \\
T9 & Mountainous soil & Ain bouziane & Skikda \\
T10 & Mountainous soil & Ain bouziane & Skikda \\
T11 & Mountainous soil & Ain bouziane & Skikda \\
T12 & Mountainous soil & Khmis meliana & Ain Defla \\
T13 & Agricultural soil (wheat) & Oum tboul & Skikda \\
T14 & Agricultural soil (wheat) & Ouled Rahmoune & Constantine \\
T15 & Forest soil & Lazharia & Tissemsilt \\
\hline
\end{tabular}

growth chamber (tubes and pots tests) to evaluate the antagonistic effect of Trichoderma isolates on the severity of FCR. Three other local durum wheat cultivars (Setifis, Waha, and Bousselem), widely grown in Algeria, were also used for the last test in greenhouse to evaluate the biocontrol effect of Trichoderma isolate on FHB. All cultivars used in this study were kindly provided by the National Institute of Agronomic Research of Algeria (INRAA).

\section{In vitro antagonistic activity of Trichoderma isolates} Antagonism by direct confrontation (DC)

Confrontations between the antagonist Trichoderma sp. and the pathogen F. culmorum were carried out according to Hibar et al. (2004). A mycelial disc (5 mm) of each fungus was placed at opposite poles on boxes containing the potato sucrose agar (PSA) medium, keeping a distance of $30 \mathrm{~mm}$ between the two fungi and incubated at $28{ }^{\circ} \mathrm{C}$ for 5 days. Three replicates were done for each Trichoderma sp./F. culmorum combination. Boxes containing only $F$. culmorum strains were used as controls (Fig. 1).

\section{Antagonism by indirect confrontation (IC)}

It was realized according to Daami-Remadi and El Mahgjoub (2001). Discs of the antagonistic isolate Trichoderma sp. and the pathogenic strain F. culmorum (5 $\mathrm{mm}$ of diameter) were deposited in two separate dishes containing the PSA medium. An assembly was carried out by superimposing the two dishes, Trichoderma sp. at the bottom and F. culmorum at the top. The junction between the two dishes was ensured by parafilm in order

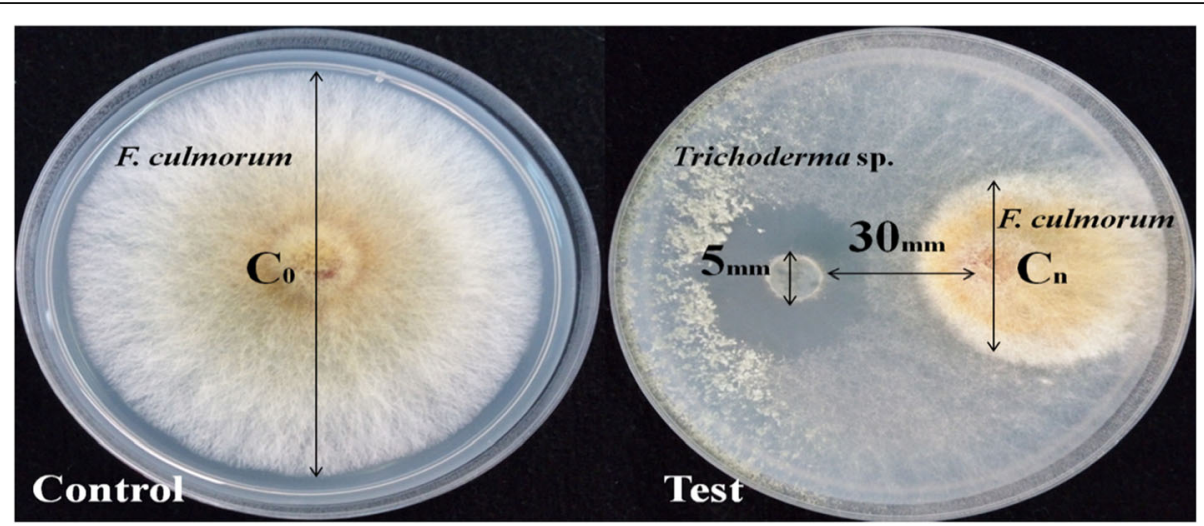

Fig. 1 Demonstrative schema of the different measurements used to calculate the percentage of mycelial growth inhibition for in vitro confrontation Trichoderma/F. culmorum 
to avoid any loss of volatile substances. The dishes were incubated in the dark at $28{ }^{\circ} \mathrm{C}$ for 5 days. The control was formed by superimposing two dishes, the upper one containing a Fusarium disc, while the lower one contained only the PSA medium.

\section{Measurement of the inhibition exerted by Trichoderma spp. I (\%)}

It was estimated according to Hmouni et al. (1996) by calculating the percentage inhibition of mycelial growth of F. culmorum strains as follows: $I(\%)=\left(1-\left(\mathrm{C}_{\mathrm{n}} / \mathrm{C}_{0}\right)\right) \times$ 100

Where $C_{\mathrm{n}}$ : diameter of the colony of the pathogen $(F$. culomrum) in the presence of the antagonist (Trichoderma sp.) $(\mathrm{mm})$ and $C_{0}$ : diameter of the control colony (mm) (Fig. 1).

\section{In vivo antagonistic activity of Trichoderma isolates}

The highly antagonistic T14 isolate, on the basis of its in vitro efficacy, was chosen to evaluate its biocontrol effect in vivo.

\section{Inocula preparation}

Fungal discs (13 mm of diameter) of the 2 fungi (Fusarium and Trichoderma), used in the tests, were obtained from 7-day-old young cultures on PSA medium. The inoculation suspension was prepared according to the protocol of Stein et al. (2009). The FC2 strain was grown on 6 Petri dishes on PSA medium for 45 days. Ten milliliter sterile of distilled water with $0.05 \%(\mathrm{v} / \mathrm{v})$ Tween 20 was added to the mycelial aerial part on the surface of each plate, and then carefully scraped off until the surface part of the fungus was recovered. The mixture of macroconidia, mycelium, and PSA medium was recovered in a beaker and then filtered through a double layer of cheesecloth. The concentration of the macroconidial suspension $8 \times 10^{6}$ macroconidia/ml was adjusted, using Malassez cell, for the inoculation test of the spike in greenhouse. The same protocol was followed for the preparation of the spore suspension of the T14 isolate, except that the culture on PSA medium lasted only 1 week (rapid sporulation), with a concentration of $8 \times$ $10^{8}$ spores $/ \mathrm{ml}$, for the spike inoculation test in greenhouse. All inocula were stored at $4{ }^{\circ} \mathrm{C}$ until use.

\section{Crown inoculation test in assay tubes}

This test was inspired by the method of Asad et al. (2009) with major modifications. Seventy-five assay tubes $(14 \mathrm{~cm} \times 3 \mathrm{~cm})$ were filled with $4 \mathrm{~cm}$ of cotton, and then $20 \mathrm{ml}$ of distilled water was added to each tube and covered with aluminum foil, then sterilized by autoclaving at $180{ }^{\circ} \mathrm{C}$ for $2 \mathrm{~h}$. Three hundred seventy-five seeds of Simeto durum wheat, surface disinfected with $2 \%$ sodium hypochlorite $(\mathrm{NaClO})$ for $5 \mathrm{~min}$ and rinsed 3 times with sterile distilled water, were placed on the wet cotton swab in each test tube (5 seeds/tube). The tubes were closed with transparent caps and placed in the oven at $28 \pm 1{ }^{\circ} \mathrm{C}$ for 4 days, where the seedlings reached the one-leaf stage (Zadoks' GS 11), the inoculation took place as follows: 25 control tubes; 25 tubes inoculated by FC2 (13 mm disc); 25 tubes inoculated by $\mathrm{FC} 2+\mathrm{T} 14$ (13 $\mathrm{mm}$ disc for both).

After inoculation, the tubes were transferred to a growth chamber $\left(25 / 19{ }^{\circ} \mathrm{C}\right.$ day/night temperature, $16 / 8$ $\mathrm{h}$ light/dark cycle) for 10 days; they were arranged according to a complete randomization plan. When the seedlings reached the two-leaf stage (Zadoks' GS 12), the seedlings were carefully removed from the cotton with water. The FCR severity classes for crown discoloration were assigned to the laboratory on a scale of 0 to 4 where class $0=$ healthy crown; 1 = light browning of crown; 2 = half browning of crown; 3 = full browning of crown; and 4 = death of seedlings.

The disease severity (DS) of each treatment was calculated using McKinney's (1923) index, which expresses the percentage of disease severity (i.e., 100) according to the formula:

$$
\mathrm{DS}=\left\{\sum(\mathrm{c} \times \mathrm{f}) / \mathrm{n} \times \mathrm{N}\right\} \times 100
$$

Where $c$ = disease class, $f=$ frequency, $n=$ number of observations, and $N=$ the highest value of the empirical scale adopted (class 4). The whole test was repeated twice in succession.

\section{Crown inoculation test in pots}

Thirty pots of $(8 \times 12 \mathrm{~cm})$ were used. For each pot, 5 durum wheat (Simeto) seeds were sterilized and sown as indicated in the previous test. All the pots were placed in the growth chamber $\left(25 / 19^{\circ} \mathrm{C}\right.$ day/night temperature, 16/8-h light/dark cycle). After 3 weeks, the seedlings reached the two-leaf stage (Zadoks' GS 12). The soil around the seedlings was removed, and the inocula discs prepared as mentioned above were placed around the stems, one disc for each stem $2 \mathrm{~cm}$ below the soil; the pots were inoculated as follows:

Ten control pots (uninoculated); 10 inoculated pots with FC2 with $13 \mathrm{~mm}$ disc; 10 inoculated pots with FC2 + T14 (13 $\mathrm{mm}$ disc versus $13 \mathrm{~mm}$ disc).

The soil was then placed back around the stems, and the pots were organized according to a completely random plan. Three weeks after inoculation, the plants reached the early tillering stage (Zadoks' GS 20), each plant was carefully removed from the soil and washed with tap water. Severity classes were assigned on the same scale and the DS was calculated using McKinney's (1923) index, as shown above. Koch's postulates were satisfied by re-isolating FC2 from brown spots on the 
coleoptiles for both tests. The whole test was repeated twice in succession. To measure the efficacy of T14 biocontrol against FCR, the reduction percentage in DS is measured for both tests as follows:

$$
\% \mathrm{DS} \text { reduction }=100-\left\{\frac{\mathrm{DS}_{\mathrm{FC} 2+\mathrm{T} 14} \times 100}{\mathrm{DS}_{\mathrm{FC} 2}}\right\}
$$

\section{Test of spike inoculation in greenhouse}

A total of 48 pots $(24 \times 20 \mathrm{~cm})$ filled with a mixture of soil/compost $(1 / 2)$ previously sterilized at $180^{\circ}$ for $2 \mathrm{~h}(2$ repetitions $24 \mathrm{~h}$ apart) were used. One hundred twenty seeds of each of the 4 cultivars (Simeto, Waha, Bousselem, Setifis) were surface-sterilized with $2 \% \mathrm{NaClO}$ for 5 $\mathrm{min}$, and rinsed 3 times with sterile distilled water, were sown $(10$ seeds/pot) under the soil surface at about 2 $\mathrm{cm}$. The plants were grown in the greenhouse. The soil was watered every 3 days. The inoculation took place at the flowering stage (Zadoks' GS 60) and each spike between the first and the third day after the first anthers emergence was labeled.

The inoculation suspension for each cultivar was done as follows: 10 seeds in a control pot (no inoculation); 10 seeds in a pot for inoculation with FC2 $\left(8 \times 10^{6}\right.$ macroconidia/ml); 10 seeds in a pot for inoculation with FC2 + T14 (mixture: $8 \times 10^{6}$ macroconidia $/ \mathrm{ml}+8 \times$ $10^{8}$ spores $/ \mathrm{ml}$ ); and 10 seeds in a pot for inoculation with T14 only, with 2 repetitions of each case for each culti$\operatorname{var}(12$ pots/cultivar).

The inoculation with the FC2 macroconidial suspension prepared previously as indicated above was carried out by spraying about $2 \mathrm{ml}$ of suspension on both sides of the spike, in a Plexiglas cage. The spikes were then covered with a transparent polyethylene bag for $72 \mathrm{~h}$ in order to maintain maximum relative humidity, necessary for the early stages of fungal development. After 15 days of inoculation, a visual disease assessment was performed for each spike by counting the percentage of symptomatic spikelets (PSS) of each inoculated spike. Approximately 8 to 10 heads were noted in each pot.

Because of the variability and specificity of each cultivar (inter and intra-genotype), flowering did not take place on the same day, even within the same genotype. Spike PSS scoring was done separately. For each spike, 5 readings with 4 days interval were done, thus illustrating the kinetics of the disease over approximately 20 days. The area under the disease progress curve (AUDPC) standard illustrated the kinetics of disease progression in PSS between the first and last scoring. AUDPC for FHB incidence was measured by the number of days of observation and calculated as described by Siou et al. (2015):

$$
\text { AUDPC }=\left\{\sum_{0}^{\mathrm{n}}\left[\left(\frac{\mathrm{Y}_{\mathrm{i}}+\mathrm{Y}_{\mathrm{i}+1}}{2}\right) \mathrm{x}\left(\mathrm{t}_{\mathrm{i}+1}-\mathrm{t}_{\mathrm{i}}\right)\right]\right\} /\left\{\mathrm{t}_{\mathrm{n}}-\mathrm{t}_{0}\right\}
$$

Where Yi the PSS at the $i$ th scoring, $t_{\mathrm{i}}$ the number of days elapsed between inoculation and the last scoring, $t_{0}$ the number of days elapsed between inoculation and the 1 st scoring and $\mathrm{n}$ the total number of scoring.

At maturity, each spike was harvested. The spikes were deseeded by hand in order to recover all the grains. All the grains were counted and weighed in order to obtain thousand kernel weight (TKW) of inoculated and uninoculated spikes (control) of each cultivar, the reduction percentage of AUDPC is measured in order to estimate the loss percentage of FHB severity resulting from biocontrol by T14.

$$
\% \text { AUDPCreduction }=100-\left\{\frac{\mathrm{AUDPC}_{\mathrm{FC} 2+\mathrm{T} 14} \times 100}{\mathrm{AUDPC}_{\mathrm{FC} 2}}\right\}
$$

Koch's postulates were satisfied by re-isolating the FC2 pathogen from the infected grains.

\section{Physical properties of the grain}

In order to fully understand the effect of T14 treatment on the physical properties of the grains, the different grains from the greenhouse spike inoculation test (control, FC2 infected, FC2 infected and treated with T14, and treated with T14 only) were compared. The four types of grain for each cultivar tested were cleaned manually. Broken and immature kernels were removed. Ten grains were taken at random and their three linear dimensions: length $\mathrm{L}$, width $\mathrm{W}$, and thickness $\mathrm{T}$; were measured, using a digital caliper $(0-150 \mathrm{~mm})$ with an accuracy of $0.01 \mathrm{~mm}$.

\section{Molecular characterization of T14 isolate}

To identify the isolate T14, which presented the best biocontrol efficiency, molecular identification was performed by the BIOfidal laboratory (CEDEX-France).

\section{DNA extraction}

DNA was extracted from mycelium collected by scraping the surface of Petri dishes cultures of purified isolate. One hundred microliters of lysis buffer $(50 \mathrm{mM}$ Tris$\mathrm{HCl} \mathrm{pH} \mathrm{7.5,} 50 \mathrm{mM}$ EDTA, 3\% SDS and 1\% 2mercaptoethanol) was added and the nucleic acids were isolated according to the microwave mini-prep procedure described by Goodwin and Lee (1993). The final DNA pellet was supplemented into $100 \mu \mathrm{l}$ TE buffer (10 $\mathrm{mM}$ Tris- $\mathrm{HCl} \mathrm{pH}$ 8.0, $0.1 \mathrm{mM}$ EDTA) and stored at $20{ }^{\circ} \mathrm{C}$ until used. 


\section{PCR amplifications and DNA sequencing}

The internal transcribed spacer (ITS1) and the translation elongation factor (TEF1- $\alpha$ ) were amplified using primer pairs ITS1 (5' TCC GTA GGT GAA CCT GCG G '3) (White et al. 1990) and EF1-728F (5' CAT CGA GAA GTT CGA GAA GG 3') (Carbone and Kohn 1999). All amplification reactions were performed in a $50-\mu \mathrm{l}$ reaction volume containing $75 \mathrm{mM}$ Tris- $\mathrm{HCl} \mathrm{pH}$ 9.0, $20 \mathrm{mM}$ (NH4)2SO4, 0.01\% (w/v) Tween 20, $1.5 \mathrm{mM}$ $\mathrm{MgCl} 2,200 \mathrm{lM}$ each dNTP, 1 unit of thermostable DNA polymerase (GoTaq, Promega), and $400 \mathrm{nM}$ of each relevant oligonucleotide primer. After electrophoresis in $1.2 \%$ agarose gels in $0.5 \times$ TAE buffer $(20 \mathrm{mM}$ Trisacetate $\mathrm{pH} 8,0.5 \mathrm{mM}$ EDTA), DNA was visualized by Ethidium bromide staining and UV illumination.

PCR products (amplified DNA) were purified by minicolumn centrifugation (NucleoSpinVR Extract II) and the DNA binds in the presence of a chaotropic salt to a silica membrane. The binding mixture was loaded directly onto NucleoSpinVR Extract II columns. Contaminations were removed by a washing step with ethanolic NT3 buffer. Finally, the pure DNA was eluted under low ionic strength conditions with a slightly alkaline NE buffer (5 mM Tris-Cl, pH 8.5). The sequences of EF1 and ITS region thus obtained were submitted to GenBank database through Submission Portal (a World Wide Web sequence submission server available at NCBI home page: http://www.ncbi. nlm.nih.gov).

\section{Statistical analysis}

Data from in vitro and in vivo assays were subjected to analysis of variance (ANOVA). The histograms were made, using Software SPSS (IBM SPSS Statistics version $25)$, and means compared by Tukey's test $(P<0.05)$. The correlation between $\mathrm{AUDPC}_{\mathrm{FC} 2}$ and $\mathrm{AUDPC}_{\mathrm{FC} 2}+$ T14 was determined by Pearson correlation. The

Table 2 The percentage of inhibition of Trichoderma isolates on Fusarium culmorum strains in both cases of confrontation (direct and indirect) after 5 days incubation

\begin{tabular}{|c|c|c|c|c|c|c|c|c|}
\hline \multirow{2}{*}{$\begin{array}{l}\text { Mean inhibition } I \% \\
\text { Trichoderma } \\
\text { isolates }\end{array}$} & \multicolumn{2}{|l|}{ FC11 } & \multicolumn{2}{|l|}{ FC2 } & \multicolumn{2}{|l|}{ FC4 } & \multicolumn{2}{|l|}{ FC20 } \\
\hline & Direct & Indirect & Direct & Indirect & Direct & Indirect & Direct & Indirect \\
\hline T1 & $30.46 \pm 2.51^{a}$ & $10.00 \pm 1.08^{a}$ & $\begin{array}{l}14.77 \pm \\
1.37^{a}\end{array}$ & $0.00 \pm 0.00^{a}$ & $18.18 \pm 1.74^{a}$ & $6.97 \pm 2.40^{a}$ & $11.49 \pm 1.51^{a}$ & $9.52 \pm 1.50^{\mathrm{abc}}$ \\
\hline $\mathrm{T} 2$ & $63.57 \pm 4.51^{\mathrm{de}}$ & $1750 \pm 2.40^{\mathrm{ab}}$ & $\begin{array}{l}31.81 \pm \\
2.97^{b}\end{array}$ & $0.00 \pm 0.00^{a}$ & $67.04 \pm 3.05^{c}$ & $30.23 \pm 1.29^{e}$ & $41.37 \pm 1.62^{c}$ & $13.09 \pm 2.34^{\mathrm{cd}}$ \\
\hline T3 & $63.57 \pm 6.64^{\text {de }}$ & $\begin{array}{l}36.25 \pm \\
4.21^{\text {cde }}\end{array}$ & $29.54 \pm 2.8^{b}$ & $0.00 \pm 0.00^{a}$ & $76.13 \pm 3.66^{\text {def }}$ & $17.44 \pm .93^{c}$ & $49.42 \pm 1.98^{\mathrm{cd}}$ & $20.23 \pm 1.95^{e f}$ \\
\hline $\mathrm{T} 4$ & $\begin{array}{l}51.65 \pm \\
4.19^{\mathrm{bcd}}\end{array}$ & $28.75 \pm 4.54^{c}$ & $\begin{array}{l}57.95 \pm \\
6.54^{c}\end{array}$ & $0.00 \pm 0.00^{a}$ & $\begin{array}{l}73.86 \pm \\
2.84^{\text {cdef }}\end{array}$ & $23.25 \pm 1.58^{d}$ & $49.42 \pm 7.02^{\mathrm{cd}}$ & $5.95 \pm .95^{\mathrm{ab}}$ \\
\hline $\mathrm{T} 5$ & $47.68 \pm 5.13^{b}$ & $27.50 \pm 4.51^{b c}$ & $\begin{array}{l}48.86 \pm \\
1.83^{c}\end{array}$ & $17.07 \pm 2.25^{b}$ & $70.45 \pm 1.63^{\mathrm{cd}}$ & $16.27 \pm 1.26^{c}$ & $49.42 \pm 5.28^{c d}$ & $14.28 \pm 2.38^{\mathrm{cd}}$ \\
\hline T6 & $48.34 \pm 3.68^{b c}$ & $\begin{array}{l}32.50 \pm \\
2.38^{\text {cde }}\end{array}$ & $\begin{array}{l}47.72 \pm \\
2.97^{c}\end{array}$ & $18.29 \pm 2.96^{\mathrm{b}}$ & $65.90 \pm 5.87^{c}$ & $38.37 \pm 2.03^{f}$ & $43.67 \pm 1.32^{c}$ & $15.47 \pm 1.80^{\text {de }}$ \\
\hline T7 & $39.07 \pm 3.31^{a b}$ & $30.00 \pm 2.32^{c}$ & $\begin{array}{l}54.54 \pm \\
2.74^{c}\end{array}$ & $0.00 \pm 0.00^{a}$ & $85.22 \pm 2.29^{9}$ & $46.51 \pm .78^{\mathrm{g}}$ & $48.27 \pm 2.58^{\mathrm{cd}}$ & $4.76 \pm 1.22^{a}$ \\
\hline T8 & $48.34 \pm 4.62^{b c}$ & $42.50 \pm 4.84^{\mathrm{ef}}$ & $\begin{array}{l}14.77 \pm \\
2.74^{\mathrm{a}}\end{array}$ & $\begin{array}{l}19.51 \pm \\
2.61^{b c}\end{array}$ & $72.72 \pm 2.32^{\text {cde }}$ & $30.23 \pm 1.07^{\mathrm{e}}$ & $52.87 \pm 2.06^{\text {de }}$ & $13.09 \pm 1.64^{\mathrm{cd}}$ \\
\hline T9 & $67.54 \pm 1.82^{e}$ & $48.75 \pm 4.30^{f g}$ & $\begin{array}{l}70.45 \pm \\
2.71^{d}\end{array}$ & $\begin{array}{l}29.26 \pm \\
1.96^{\mathrm{de}}\end{array}$ & $81.81 \pm 2.43^{\mathrm{fg}}$ & $\begin{array}{l}27.90 \pm \\
3.14^{\mathrm{de}}\end{array}$ & $67.81 \pm 1.71^{h}$ & $25.00 \pm 1.42^{f}$ \\
\hline T10 & $\begin{array}{l}50.99 \pm \\
7.87^{\mathrm{bcd}}\end{array}$ & $30.00 \pm 2.61^{c}$ & $\begin{array}{l}54.54 \pm \\
5.10^{c}\end{array}$ & $0.00 \pm 0.00^{a}$ & $\begin{array}{l}73.86 \pm \\
3.18^{\text {cdef }}\end{array}$ & $32.55 \pm 2.20^{e}$ & $\begin{array}{l}56.32 \pm \\
1.94^{\text {def }}\end{array}$ & $\begin{array}{l}10.71 \pm \\
1.87^{\text {cde }}\end{array}$ \\
\hline T11 & $44.37 \pm 7.26^{\mathrm{ab}}$ & $\begin{array}{l}35.00 \pm \\
2.95^{\text {cde }}\end{array}$ & $\begin{array}{l}13.63 \pm \\
3.01^{a}\end{array}$ & $\begin{array}{l}24.39 \pm \\
2.32^{\mathrm{cd}}\end{array}$ & $39.77 \pm 2.72^{b}$ & $48.83 \pm 1.64^{g}$ & $25.28 \pm 1.82^{b}$ & $47.61 \pm 3.86^{h}$ \\
\hline $\mathrm{T} 12$ & $67.54 \pm 7.51^{e}$ & $50.00 \pm 3.73^{\mathrm{fg}}$ & $\begin{array}{l}77.27 \pm \\
6.53^{d}\end{array}$ & $32.92 \pm 1.23^{e}$ & $71.59 \pm 1.76^{\mathrm{cd}}$ & $55.81 \pm 2.85^{h}$ & $\begin{array}{l}62.06 \pm \\
2.35^{\mathrm{fgh}}\end{array}$ & $48.80 \pm 1.95^{h}$ \\
\hline T13 & $45.69 \pm 2.31^{b}$ & $31.25 \pm 4.39^{c d}$ & $\begin{array}{l}34.09 \pm \\
2.19^{b}\end{array}$ & $2.43 \pm 1.00^{\mathrm{a}}$ & $\begin{array}{l}73.86 \pm \\
1.69^{\text {cdef }}\end{array}$ & $\begin{array}{l}12.79 \pm \\
1.02^{b c}\end{array}$ & $42.52 \pm 1.26^{c}$ & $30.95 \pm 1.04^{g}$ \\
\hline T14 & $\begin{array}{l}62.91 \pm \\
2.52^{\text {cde }}\end{array}$ & $56.25 \pm 4.18^{g}$ & $\begin{array}{l}79.54 \pm \\
4.65^{d}\end{array}$ & $\begin{array}{l}21.95 \pm \\
2.91^{b c}\end{array}$ & $80.68 \pm 2.12^{\mathrm{efg}}$ & $44.18 \pm 1.45^{9}$ & $65.51 \pm 1.61^{g h}$ & $13.09 \pm 2.31^{c d}$ \\
\hline T15 & $46.35 \pm 4.13^{b}$ & $41.25 \pm 3.81^{\text {def }}$ & $\begin{array}{l}57.95 \pm \\
1.86^{c}\end{array}$ & $17.07 \pm 2.11^{b}$ & $72.72 \pm 2.20^{\text {cde }}$ & $10.46 \pm .79^{\mathrm{ab}}$ & $\begin{array}{l}58.62 \pm \\
1.58^{\mathrm{efg}}\end{array}$ & $5.95 \pm 0.86^{a b}$ \\
\hline
\end{tabular}


coefficient of correlation was found to be significant at the 5\% level $(P \leq 5 \%)$.

\section{Results}

In vitro effect of Trichoderma isolates on F. culmorum strains

The antagonistic effect in direct confrontation (DC) of Trichoderma isolates against $F$. culmorum varies widely from isolate to isolate. Three isolates T9, T12, and T14 had the highest and most stable levels of inhibition with all strains of $F$. culmorum. Inhibition values ranged from 62.06 to $81.81 \%$ (Table 2, Fig. 2). The antagonistic effect in indirect confrontation (IC) is less important for all Trichoderma spp., except T11 against FC2, FC4, and FC20 where IC is greater than DC $(24.39 \%$ and $48.83 \%$, $47.61 \%$ ), respectively (Table 2, Fig. $3 \mathrm{~b}-\mathrm{d}$ ). T9, T12, and T14 were also the most reliable in the IC with maximum values of $48.75 \%, 55.81 \%$, and $56.25 \%$, respectively.

The T1 isolate recorded the lowest rates in both confrontations (DC and IC), and with all strains of F. culmorum. It is therefore far from being chosen for a biocontrol role against FCR and FHB. On the other hand, maximum growth inhibition $(85.22 \%)$ was obtained by T7 against FC4 in DC. Some Trichoderma isolates had a very low inhibition percentage with null values for T1, T2, T3, T4, T7, and T10 for IC with FC2 (Table 2). A graphical presentation summarizes the DC and IC results of the in vitro test, to better compare the effect of Trichoderma isolates on each strain of F. culmorum separately was shown in Fig. 3).

\section{In vivo effect of T14 in reducing FCR in both tube and pot tests}

FC2 induced FCR for the cultivar Simeto with 68 and $60.5 \%$, respectively. A significant decrease in the aggressiveness of DS disease per T14 with considerable \%DS reduction rates of 50 and $63.63 \%$ was observed (Table $3)$.

\section{In vivo effect of $\mathrm{T} 14$ in the reduction of $\mathrm{FHB}$}

All cultivars were affected by FHB due to FC2 inoculation (Table 4 and Fig. 4). The highest disease severity recorded by the AUDPC standard was in Simeto and Waha cultivars with 63.37 and 56.27\%, respectively, while cultivars Bousselem and Setifis showed some resistance to FHB with AUDPC $=18.94 \%$ and $16.38 \%$, respectively (Table 4 and Fig. 5a).

A remarkable improvement for the thousand kernel weight (TKW) inoculated and treated with FC2 + T14 was observed, compared to the one inoculated with FC2

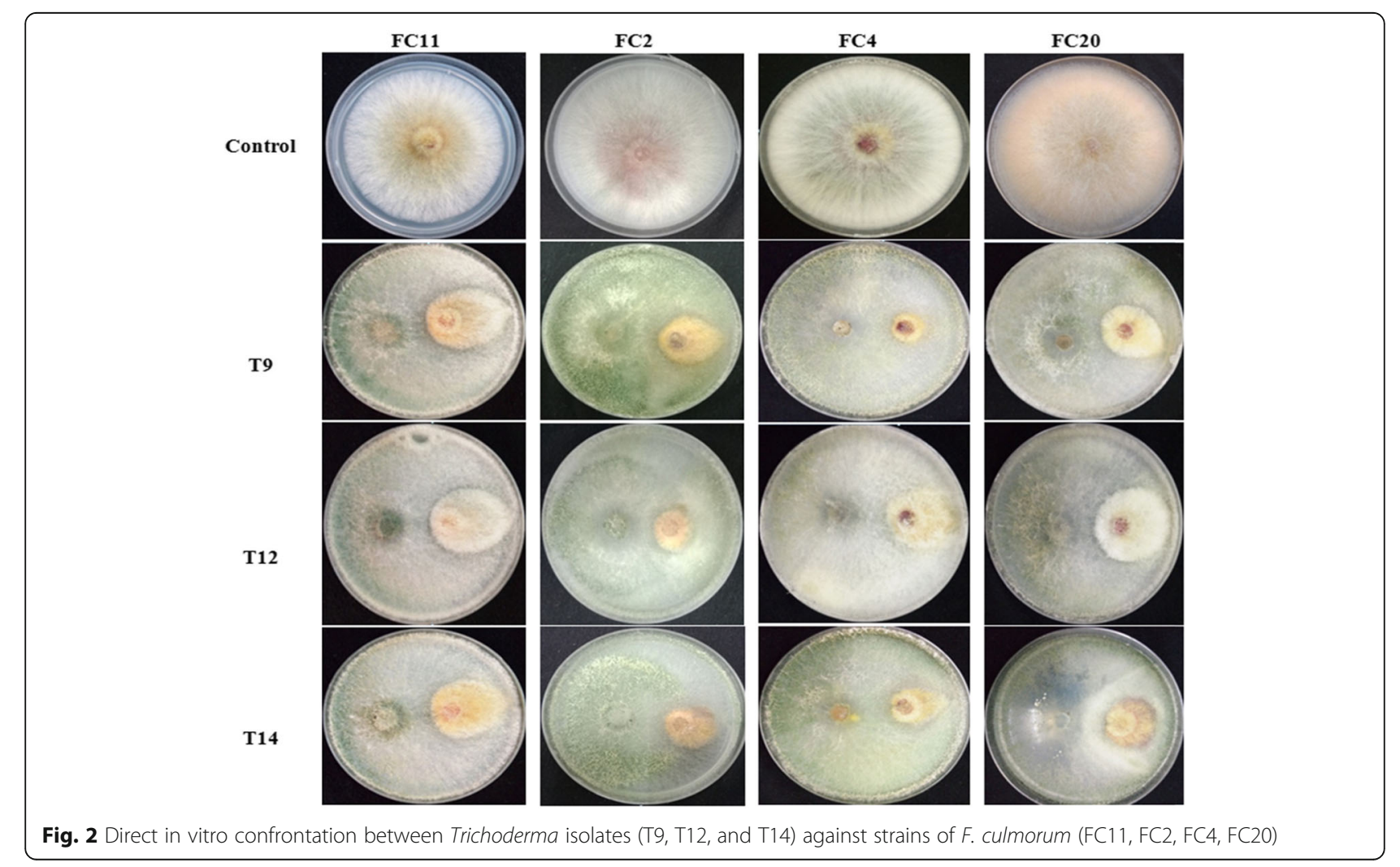



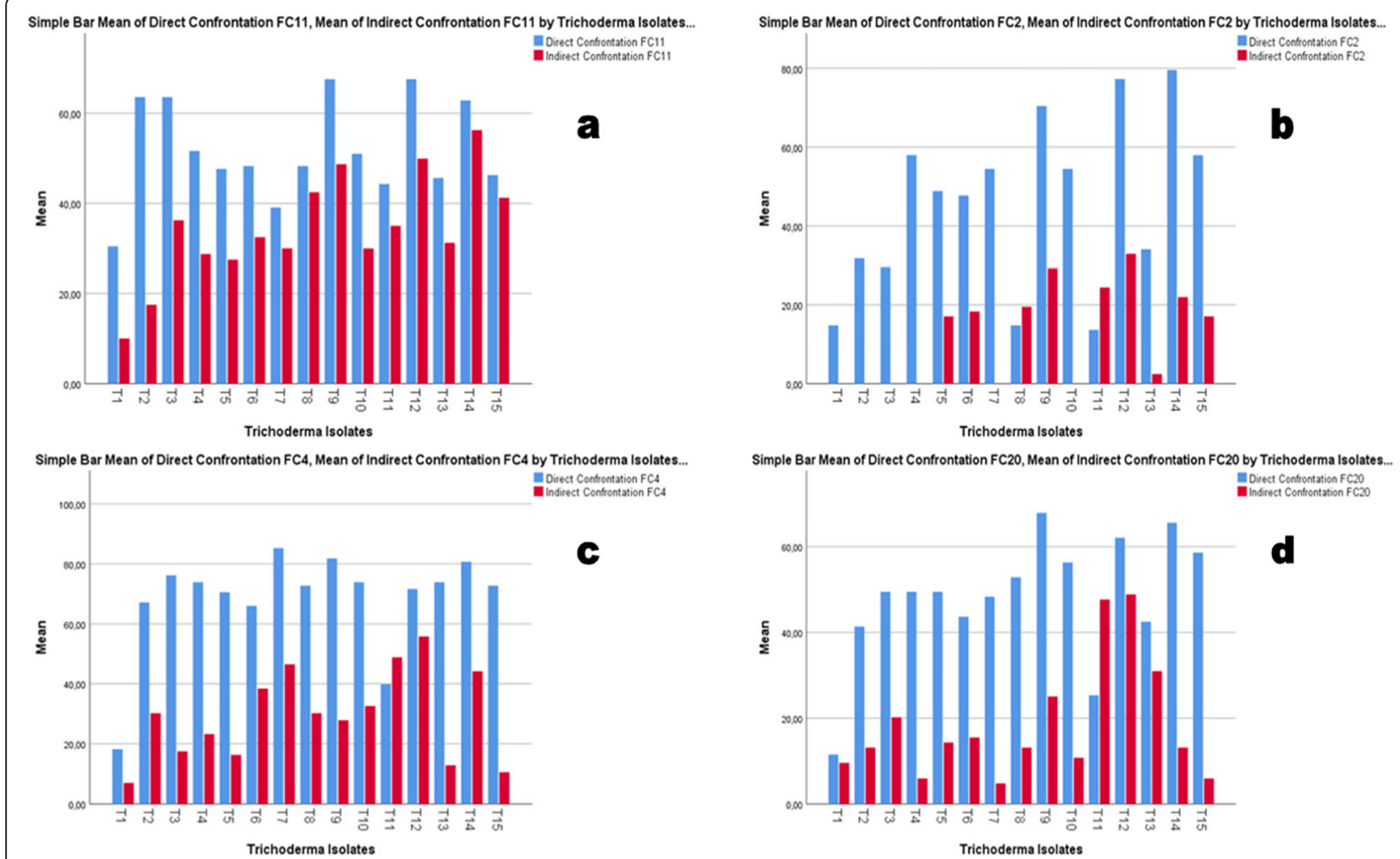

Fig. 3 Histograms of in vitro confrontation (direct and indirect) between Trichoderma isolates against F. culmorum FC11 (a), FC2 (b), FC4 (c), FC20 (d)

in two cultivars, but a slight decrease was observed for Setifis and Waha, where $\mathrm{TKW}_{\mathrm{FC} 2}+\mathrm{T} 14^{<} \mathrm{TKW}_{\mathrm{FC} 2}$. The antagonistic effect of T14 in the $\mathrm{FC} 2+\mathrm{T} 14$ mixed inoculum significantly reduced the percent severity of FHB disease for all cultivars with very high reduction rates (74.60\% for Setifis) (Table 4 and Fig. 5b). A slight decrease of $\mathrm{TKW}_{\mathrm{T} 14}$ than the control $\left(\mathrm{TKW}_{\mathrm{T} 14}<\mathrm{TKW}_{\text {con- }}\right.$ trol), was recorded for all tested cultivars. This decrease remained negligible and significantly better than the $\mathrm{Fu}$ sarium-treated $\mathrm{TKW}_{\mathrm{T} 14}>\mathrm{TKW}_{\mathrm{FC} 2}+\mathrm{T} 14^{>} \mathrm{TKW}_{\mathrm{FC} 2}$, only the $\mathrm{cv}$. Setifis was the exception (Table 4).

\section{Effect of T14 on physical properties of grain}

Results showed that for the length parameter L, the difference among the four grain types was not statistically significant, even for the four cultivars. On the other hand, the parameters width $\mathrm{W}$ and thickness $\mathrm{T}$ show a very significant variation, the measurements of grains infected with $\mathrm{FC} 2$ are the smallest, followed by grains infected with FC2 and treated with T14, due to the antagonistic effect of T14 used as biocontrol agent, the values of the control grains and the one treated only with T14 are almost similar (Table 5).

\section{Molecular identification of T14}

The amplification of DNA regions with primers TEF1- $\alpha$ and ITS1 was successfully used to identify T14. The final sequences size used for identification analysis were 565 and $533 \mathrm{bp}$, respectively (Fig. 6). TEF1- $\alpha$ and ITS 1 sequences were submitted to NCBI GenBank and accession numbers were given as MW171248 and MW159753, respectively. The isolate T14 was identified as Trichoderma afroharzianum.

Table 3 Severity of FCR inoculated by FC2 and reduction percentage induced by T14, in both in vivo tube and pot tests

\begin{tabular}{llllll}
\hline & \multicolumn{2}{l}{ Tubes test } & & & Pots test \\
\cline { 2 - 3 } \cline { 5 - 6 } Inoculum & DS (mean \pm Std. Dev) & \%DS reduction & & DS (mean \pm Std. Dev) & \%DS reduction \\
\hline FC2 (disc 13 mm) & $68 \pm 2.35$ & 0 & $60.5 \pm 7.08$ & 0 \\
FC2 (disc) + T14 (disc) & $34 \pm 6.62$ & 50 & $/$ & $22 \pm 3.08$ & 63.63 \\
Control & 0 & $/$ & 0 & $/$ \\
\hline
\end{tabular}


Table 4 Biocontrol of T14 on FHB tested on 4 durum wheat cultivars, by the AUDPC standard (FC2, FC2 + T14, \%reduction), and TKW (control, FC2, FC2 + T14, T14)

\begin{tabular}{|c|c|c|c|c|c|c|c|}
\hline \multirow[b]{2}{*}{ Cutivars } & \multicolumn{3}{|l|}{ AUDPC } & \multicolumn{4}{|l|}{ TKW (gram) } \\
\hline & FC2 & $\mathrm{FC} 2+\mathrm{T} 14$ & Reduction\% & Control & FC2 & $\mathrm{FC} 2+\mathrm{T} 14$ & T14 \\
\hline Simeto & $63.37 \pm 4.52^{b}$ & $31.83 \pm 3.16^{b}$ & 49.77 & $60.38 \pm 3.26^{b}$ & $21.93 \pm 2.31^{a}$ & $34.15 \pm 1.33^{\mathrm{a}}$ & $57.60 \pm 3.52^{b}$ \\
\hline Waha & $56.27 \pm 3.43^{b}$ & $31.83 \pm 3.84^{b}$ & 43.43 & $58.65 \pm 3.59^{b}$ & $39.25 \pm 1.73^{b}$ & $32.77 \pm 3.15^{a}$ & $40.64 \pm 2.22^{\mathrm{a}}$ \\
\hline Bousselem & $18.94 \pm 2.10^{\mathrm{a}}$ & $9.80 \pm 1.34^{\mathrm{a}}$ & 48.25 & $56.91 \pm 3.77^{b}$ & $37.38 \pm 1.60^{b}$ & $44.18 \pm 2.35^{b}$ & $50.99 \pm 2.35^{b}$ \\
\hline Setifis & $16.38 \pm 1.37^{\mathrm{a}}$ & $4.16 \pm 1.28^{\mathrm{a}}$ & 74.60 & $41.92 \pm 2.37^{\mathrm{a}}$ & $39.62 \pm 3.23^{b}$ & $37.81 \pm 5.08^{\mathrm{ab}}$ & $35.87 \pm 4.93^{\mathrm{a}}$ \\
\hline
\end{tabular}

The values (mean \pm Std. deviation) with different letters denote the statistical significance determined by ANOVA followed by Tukey test $(P<0.05)$

\section{Discussion}

In this study, the antagonistic activity of 15 unidentified Trichoderma isolates was evaluated in vitro and in vivo against 4 strains of $F$. culmorum, common causative agents of FCR and FHB in wheat. Trichoderma is a nonpathogenic fungus that provides protection to many crops against fungal diseases caused by the genus Fusarium (Tsegaye Redda et al. 2018). It is used as a biocontrol agent, avoiding the adverse effects that accompany chemical control.

Double culture techniques, as described by many previous studies, have been widely used in tests of antagonistic activities (Srivastava et al. 2010). The direct confrontation experiment showed that all Trichoderma isolates were capable of inhibiting mycelial growth of all four pathogenic strains, with rates differing from isolate to isolate and strain to strain as found by Khan et al. (2006). Differences between strains can reach an interval of more than $50 \%$, either in vitro or in vivo.

Isolates T9 $(67.54,70.45,81.81$, and $67.81 \%), \mathrm{T} 12$ (67.54, 77.27, 71.59, and 62.06\%), and T14 (62.91, 79.54,
80.68, and 65.51\%) showed the most significant rates of reduction than the controls against FC11, FC2, FC4, and FC20, respectively (Table 2 and Figs. 2 and 3). These results are significantly better than those obtained by Ann et al. (2017), where inhibition of mycelial growth of $F$. verticillioides by Trichoderma sp. was only $32 \%$ compared to control in an in vitro bi-culture test. They were similar to the result obtained by Dendouga et al. (2016), where the rate of growth reduction was $70.68 \%$, representing the efficacy of biological control of T. harzianum against $F$. culmorum by in vitro assays. We suppose therefore that $\mathrm{T} 9, \mathrm{~T} 12$, and $\mathrm{T} 14$ are part of the same species, according to some reports in the literature showing that there are no or slight differences among strains of the same species, for the control of Fusarium spp. (Khan et al. 2006).

The T7 isolate recorded the highest rate (85.22\%) against FC4, but this high score was not generalized against other strains of $F$. culmorum. The T7 isolate was excluded from in vivo testing due to its specificity as an FC4 antagonist only (Table 2 and Fig. 3c). In contrast,
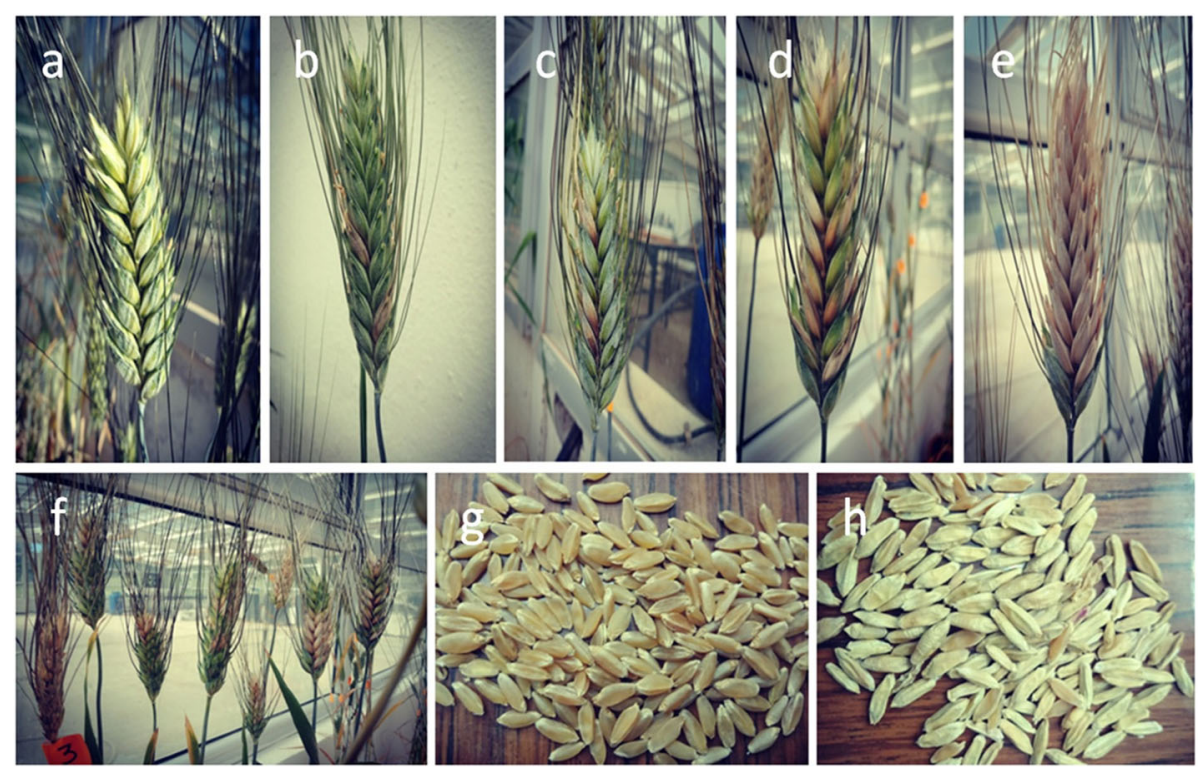

Fig. 4 Photos illustrate the different stages of FHB infection, after inoculation with FC2. a Healthy spike (control). b Start of FHB. c Spread. d 50\% fusarium spike. e 100\% fusarium spike. f Different stages of Fusarium disease in the same cultivar. $\mathbf{g}$ Healthy kernels. $\mathbf{h}$ Fusarium kernels 

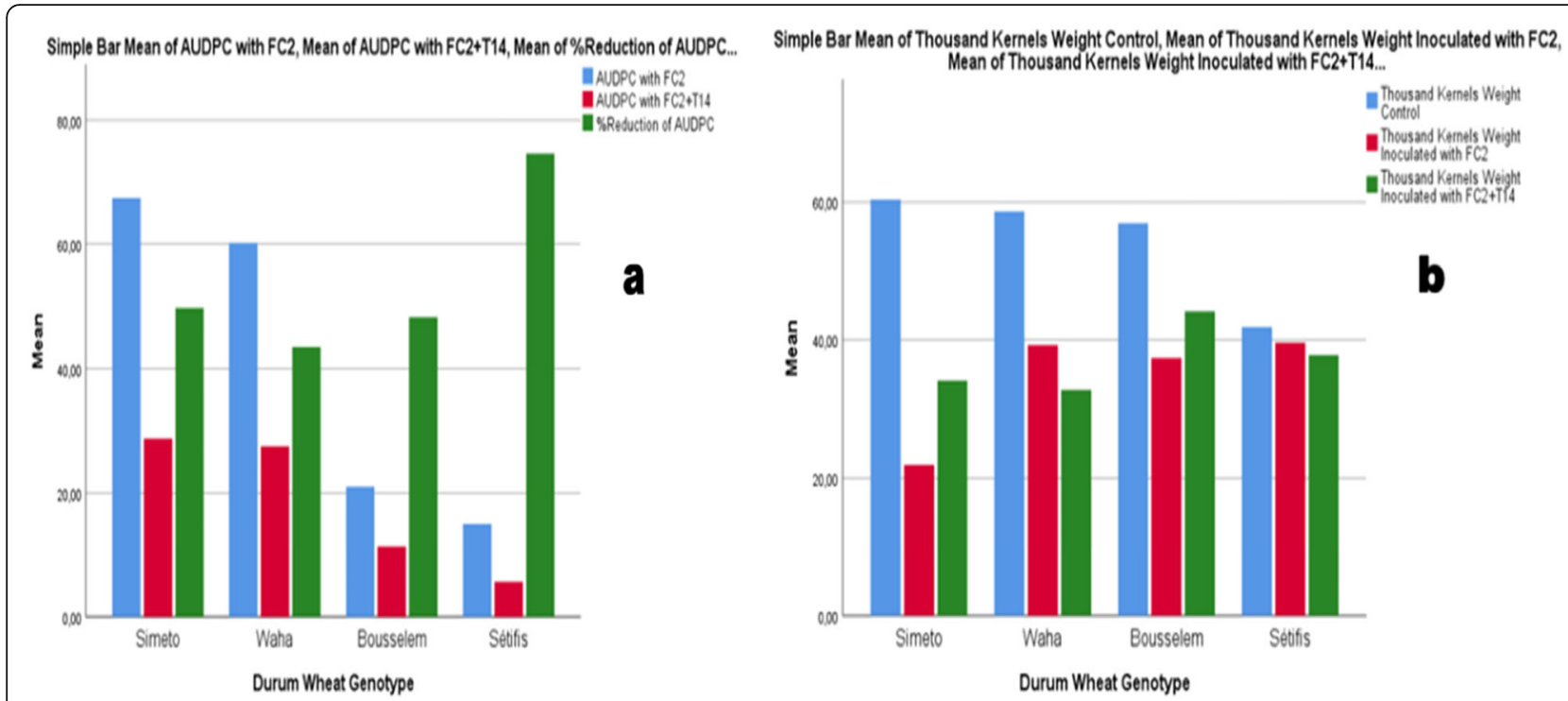

Fig. 5 Biocontrol effect of T14 on wheat FHB symptoms on the 4 cultivars tested. a On AUDPC standard. b On thousand kernels weight TKW

T1 recorded the lowest rates among all isolates with 30.46, 14.77, 18.18, and 11.49\% against FC11, FC2, FC4, and FC20, respectively (Table 2 and Fig. 3).

Trichoderma species are known to produce many volatile organic compounds (Stoppacher et al. 2010), and they also play a major role in inhibiting the growth of the pathogen. Indirect (remote) confrontation experiments showed a reduction in pathogen growth that differs from strain to strain. The T9, T12, and T14 isolates were again more effective than the other isolates studied, the reduction in growth of all 4 strains of $F$. culmorum was stable and balanced with T9 $(48.75,29.26,27.90$, and $25 \%)$, T12 (50, 32.92, 55.81, and 48.80\%), and T14 (56.25, 21.95\%, 44.18, and $13.09 \%$ ) versus FC11, FC2, FC4, and FC20, respectively (Table 2 and Fig. 3). Behzad et al. (2008) showed similar results with volatile inhibitory substances produced by
Trichoderma isolates against $F$. graminearum. The major advantage of antibiosis via volatile substances is that these substances can remain close to the spikes, thus controlling the inoculum of airborne pathogens without even establishing actual physical contact with them.

In addition, the $I \%$ recorded for $\mathrm{DC}$ is significantly higher than that recorded for IC, with the exception of the T11 isolate with FC2, FC4, and FC20, where the indirect inhibition rates were better than the direct ones, which can be explained by the volatile substances that characterize T11 compared to the others (Table 2 and Fig. $3 \mathrm{~b}-\mathrm{d})$. The $\mathrm{T} 1$ isolate always remained in last place with non-significant and almost negligible rates $(10,0$, $6.97 \%$, and $9.52 \%$ ) versus $\mathrm{FC} 11, \mathrm{FC} 2, \mathrm{FC} 4$, and $\mathrm{FC} 20$, respectively (Table 2 and Fig. 3). These results indicated

Table 5 Comparison of physical properties (length, width, thickness) of the grains of the 4 cultivars tested (control, FC2 infected, FC2 infected and treated with T14, and treated with T14 only)

\begin{tabular}{|c|c|c|c|c|c|c|c|c|c|c|c|c|}
\hline \multirow{2}{*}{$\begin{array}{l}\text { Physical properties } \\
\text { of grain } \\
\text { State } \\
\text { Cultivar }\end{array}$} & \multicolumn{4}{|c|}{ Length \pm Std deviation(mm) } & \multicolumn{4}{|c|}{ Width \pm Std deviation $(\mathrm{mm})$} & \multicolumn{4}{|c|}{ Thickness \pm Std deviation $(\mathrm{mm})$} \\
\hline & Control & $\begin{array}{l}\text { Infected } \\
\text { FC2 }\end{array}$ & $\begin{array}{l}\text { Treated } \\
\text { FC2 + } \\
\text { T14 }\end{array}$ & $\begin{array}{l}\text { Treated } \\
\text { T14 }\end{array}$ & Control & $\begin{array}{l}\text { Infected } \\
\text { FC2 }\end{array}$ & $\begin{array}{l}\text { Treated } \\
\text { FC2 + } \\
\text { T14 }\end{array}$ & $\begin{array}{l}\text { Treated } \\
\text { T14 }\end{array}$ & Control & $\begin{array}{l}\text { Infected } \\
\text { FC2 }\end{array}$ & $\begin{array}{l}\text { Treated } \\
\text { FC2+T14 }\end{array}$ & $\begin{array}{l}\text { Treated } \\
\text { T14 }\end{array}$ \\
\hline Simeto & $\begin{array}{l}8.58 \pm \\
0.30^{b}\end{array}$ & $\begin{array}{l}7.97 \pm \\
0.39^{\mathrm{ab}}\end{array}$ & $\begin{array}{l}8.39 \pm \\
0.42^{b}\end{array}$ & $\begin{array}{l}8.54 \pm \\
0.22^{b}\end{array}$ & $\begin{array}{l}3.19 \pm \\
0.17^{b}\end{array}$ & $\begin{array}{l}1.69 \pm \\
0.42^{a}\end{array}$ & $\begin{array}{l}2.60 \pm \\
0.26^{a b}\end{array}$ & $\begin{array}{l}2.97 \pm \\
0.37^{\mathrm{ab}}\end{array}$ & $\begin{array}{l}3.56 \pm \\
0.13^{b}\end{array}$ & $\begin{array}{l}2.55 \pm \\
0.34^{\mathrm{ab}}\end{array}$ & $\begin{array}{l}3.37 \pm \\
0.12^{b}\end{array}$ & $\begin{array}{l}3.48 \pm \\
0.16^{b}\end{array}$ \\
\hline Waha & $\begin{array}{l}7.99 \pm \\
0.17^{a}\end{array}$ & $\begin{array}{l}6.90 \pm \\
0.23^{a}\end{array}$ & $\begin{array}{l}7.27 \pm \\
0.32^{a}\end{array}$ & $\begin{array}{l}7.63 \pm \\
0.40^{a}\end{array}$ & $\begin{array}{l}3.23 \pm \\
0.10^{b}\end{array}$ & $\begin{array}{l}2.14 \pm \\
0.07^{b}\end{array}$ & $\begin{array}{l}2.39 \pm \\
0.35^{\mathrm{a}}\end{array}$ & $\begin{array}{l}3.15 \pm \\
0.17^{b}\end{array}$ & $\begin{array}{l}3.39 \pm \\
0.18^{a b}\end{array}$ & $\begin{array}{l}2.48 \pm \\
0.38^{a b}\end{array}$ & $\begin{array}{l}2.84 \pm \\
0.31^{a}\end{array}$ & $\begin{array}{l}3.36 \pm \\
0.22^{a b}\end{array}$ \\
\hline Bousselem & $\begin{array}{l}7.88 \pm \\
0.54^{a}\end{array}$ & $\begin{array}{l}8.13 \pm \\
0.25^{b}\end{array}$ & $\begin{array}{l}8.23 \pm \\
0.31^{b}\end{array}$ & $\begin{array}{l}8.31 \pm \\
0.25^{b}\end{array}$ & $\begin{array}{l}2.56 \pm \\
0.16^{\mathrm{a}}\end{array}$ & $\begin{array}{l}2.08 \pm \\
0.26^{\mathrm{ab}}\end{array}$ & $\begin{array}{l}2.86 \pm \\
0.14^{b}\end{array}$ & $\begin{array}{l}3.11 \pm \\
0.12^{a b}\end{array}$ & $\begin{array}{l}3.16 \pm \\
0.23^{a}\end{array}$ & $\begin{array}{l}2.44 \pm \\
0.24^{\mathrm{a}}\end{array}$ & $\begin{array}{l}3.21 \pm \\
0.12^{b}\end{array}$ & $\begin{array}{l}3.17 \pm \\
0.06^{a}\end{array}$ \\
\hline Setifis & $\begin{array}{l}7.88 \pm \\
0.25^{a}\end{array}$ & $\begin{array}{l}7.73 \pm \\
0.16^{b}\end{array}$ & $\begin{array}{l}7.99 \pm \\
0.19^{b}\end{array}$ & $\begin{array}{l}7.38 \pm \\
0.23^{\mathrm{a}}\end{array}$ & $\begin{array}{l}3.32 \pm \\
0.12^{b}\end{array}$ & $\begin{array}{l}2.34 \pm \\
0.29^{b}\end{array}$ & $\begin{array}{l}2.44 \pm \\
0.19^{a}\end{array}$ & $\begin{array}{l}2.84 \pm \\
0.16^{a}\end{array}$ & $\begin{array}{l}3.42 \pm \\
0.17^{b}\end{array}$ & $\begin{array}{l}2.84 \pm \\
0.25^{b}\end{array}$ & $\begin{array}{l}3.16 \pm \\
0.14^{b}\end{array}$ & $\begin{array}{l}3.41 \pm \\
0.19^{a b}\end{array}$ \\
\hline
\end{tabular}

The values (mean \pm Std. deviation) with different letters denote the statistical significance determined by ANOVA followed by Tukey test $(P<0.05)$ 


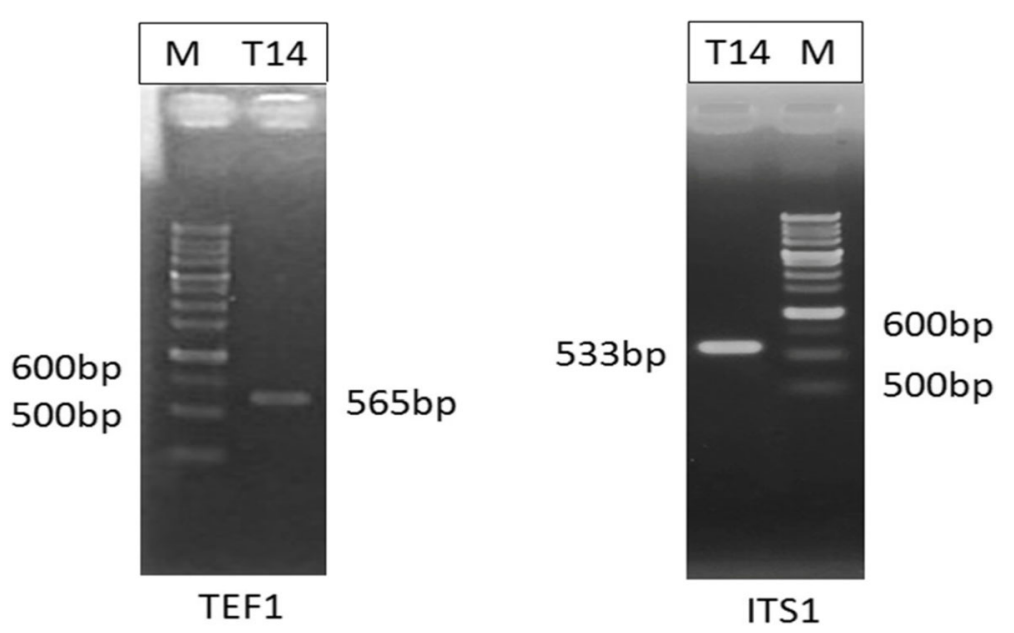

Fig. 6 Agarose gel image of PCR-amplified (TEF1 and ITS1) genes regions of T14 isolate

that not all antagonist isolates are equally effective against the pathogen.

A rapid neutralization of the pathogen was observed. All Trichoderma isolates were fast growing, with the mycelial mass invading the Petri dish in only 3 days, while the strains of the pathogen require 6 days. Rapid germination was a decisive element for the competitiveness of Trichoderma spp. in antagonism. The same observation was made by El-Komy et al. (2015). In addition to the rapid development of Trichoderma strains, they are naturally resistant to many toxic compounds, including herbicides, fungicides and pesticides, and phenolic compounds, and recover very quickly after sub-lethal doses of some of these compounds are added (Harman et al. 2004).

In the in vivo tests, in growth chamber or in greenhouse, T14 isolate was selected to be applied in vitro. This choice was supported by three reasons; firstly, the highest and most stable inhibition rates recorded against the four strains of F. culmorum; secondly, T14 recorded the best inhibition score against the pathogen FC2 in in vitro tests (79.54\%) (Table 2); and thirdly, the fact that it came from wheat rhizosphere. So, it is already adapted to the environment where it was to be applied. However, the choice of FC2 as a pathogen was random. These experiments were very useful in evaluating the in vivo efficacy of Trichoderma biocontrol in reducing FCR and FHB.

According to Erginbas-Orakci et al. (2016), there are several collar inoculation techniques for FCR (seedling dipping, droplet at the base of the stem and colonized grain). The disc technique used in this study was new and used for the first time in this study, taking into consideration the work of Dhingra and Sinclair (1985) who found that the addition of adhesive agents such as gelatin, agar, or methylcellulose is advantageous for inoculation in greenhouse and in field. The inoculation with
FC2 was performed by a mycelial disc around the stems, and the treatment is also applied in the same way for more equality in competitiveness, and more targeting of the crown.

The results obtained in growth chamber showed that FC2 strain induced FCR in all tubes and pots, with a DS\% of 68 and $60.5 \%$, respectively. While a very significant decrease in DS\% was recorded in tubes and pots treated with T14 strain, with a reduction rate of 50 and $63.63 \%$, respectively (Table 3 ). Results close to those obtained by Lu et al. (2020) with an in vivo inhibition rate of more than $50 \%$ by a strain of Trichoderma against $F$. graminearum, and $F$. verticillioides agents responsible for corn stem rot in China. Also, obtained results appeared much more interesting compared to the one obtained by Ghanbarzadeh et al. (2016), where a strain of $T$. harzianum reduced the incidence of basal rot disease in onions by only $25 \%$ against $F$. proliferatum. Nevertheless, the fungicidal seed treatment was inferior to that with Trichoderma.

In in vivo tests in the greenhouse, the application of the T14 isolate (highly antagonistic in the in vitro test) against the FC2 strain, led to a significant reduction in the AUDPC standard of FHB than the untreated inoculated control. The highest rate of reduction was achieved by the cultivar Setifis (74.60\%), followed by Simeto (49.77\%) (Table 4 and Fig. 5a). Obtained results are in agreement with those of Saharan et al. (2008), in which, Trichoderma spp. had confirmed as the most potent agents against $F u$ sarium spp. and induce inhibitory effects on the mycelial growth of F. graminearum and F. semitectum, the causative agent of FHB in wheat. Other results obtained by Mahmoud (2016) revealed that T. harzianum significantly reduced the severity of FHB caused by $F$. graminearum and F. culmorum. A highly 
significant Pearson correlation between $\mathrm{AUDPC}_{\mathrm{FC} 2}$ and AUDPC $\mathrm{FC} 2+\mathrm{T} 14_{4}$ with $r=0.955, p<0.001$, for the 4 wheat cultivars tested, confirming the positive role induced by the treatment with T14.

The lowest FHB severity was achieved by the cultivar Setifis with $\mathrm{AUDPC}_{\mathrm{FC} 2}=16.38 \%$, followed by Bousselem (18.94\%), compared to the other cultivars tested (Table 4 and Fig. 5a). This confirms the varietal resistance of these two cultivars to FHB. It is also observed that there was a clear improvement in TKW between the diseased grain and that treated with T14, except Waha and Setifis, where the $\mathrm{TKW}_{\mathrm{FC} 2}+\mathrm{T}_{14} \mathrm{TKW}_{\mathrm{FC} 2}$ for unknown reasons (Table 4 and Fig. $5 \mathrm{~b}$ ). The decrease in $\mathrm{TKW}_{\mathrm{T} 14}$ compared to the control $\left(\mathrm{TKW}_{\mathrm{T} 14}<\mathrm{TKW}_{\text {control }}\right)$ was very small and negligible, which encouraged the use of T14 as a preventive treatment without affecting yield.

Study of the physical parameters of the grains from the spike inoculation test in the greenhouse (control, FC2 infected, FC2 infected and treated with T14, and treated with T14 only) revealed that the length parameter L was not at all influenced by FC2 infection; on the other hand, the width parameter $\mathrm{W}$ and thickness parameter $\mathrm{T}$ showed that the measurements of FC2infected grains were smaller than those infected by FC2 and treated with T14, which confirmed the biocontrol effect of T14. The difference between control and T14treated grains were almost similar, which encourage the use of T14 as a preventive treatment without influencing the physical properties of the grains (Table 5).

The identification of microscopic characteristics, as well as the sequences of ITS and TEF1- $\alpha$ (Fig. 6), allowed to identify T14 isolate as T. afroharzianum, recently declared as the first report in Algeria (Benttoumi et al. 2020; Haouhach et al. 2020). Therefore, the present work was the first to use T. afroharzianum as a biocontrol agent in Algeria.

Species identification using molecular characterization tools is very useful in answering the question of whether a particular taxon is present on particular hosts or plants (Abd-Elsalam et al. 2010). This will reduce the severity of FCR and FHB diseases in wheat by using the appropriate biocontrol agent.

\section{Conclusion}

In conclusion, biocontrol agents could play an important role in the protection of wheat. Among the 15 Trichoderma spp. isolated in this study, T. afroharzianum showed promising results for the control of FCR and FHB in wheat. Trichoderma afroharzianum evaluated for the first time in Algeria as a biocontrol agent is recommended as a preventive treatment without affecting yield and without influencing the physical properties of the grains. Additionally, it comes from agricultural soil of wheat, so it is already adapted to the environment where it is to be applied.

\section{Abbreviations}

FCR: Fusarium crown rot; FHB: Fusarium head blight; \%Gl: Germination inhibition percentage; AUDPC: Area under the disease progress curve; ANOVA: Analysis of variance; TEF1-a: Translation elongation factor1-alpha; ITS1: Internal transcribed spacers; DC: Direct confrontation; IC: Indirect confrontation; PSA: Potato sucrose agar; DS: Disease severity; $\mathrm{NaClO}$ : Sodium hypochlorite; PSS: The percentage of symptomatic spikelets; TKW: Thousand kernel weight

\section{Acknowledgements}

The authors gratefully thank the Algerian Ministry of Higher Education and Scientific Research and the General Directorate of Scientific Research and Technological Development, Algeria.

\section{Authors' contributions}

$\mathrm{HB}$ conceived the work, designed and performed the experiments, analyzed the data, and wrote the paper. IB was a major contributor in writing the manuscript, reviewing, and editing the paper. WH contributed to the isolation of Trichoderma strains. SB contributed to the isolation of Trichoderma strains. AB offered the durum wheat cultivars tested. DK was responsible for the supervision and project administration. All authors have read and approved the final manuscript.

\section{Funding}

This research did not receive any specific grant from funding agencies in the public, commercial, or not-for-profit sectors.

Availability of data and materials

All data generated or analyzed during this study are included in this published article.

\section{Declarations}

Ethics approval and consent to participate Not applicable

\section{Consent for publication}

Not applicable

\section{Competing interests}

The authors declare that they have no competing interests

\section{Author details}

'Laboratoire de Génétique Biochimie et Biotechnologies Végétales, Faculté des Sciences de la Nature et de la Vie, Université Frères Mentouri

Constantine 1, 25000 Constantine, Algeria. ${ }^{2}$ Institut National de la Recherche Agronomique d'Algérie (INRAA), 25000 Constantine, Algeria. ${ }^{3}$ École Nationale Supérieure de Biotechnologie, Pôle Universitaire, Nouvelle Ville Ali Mendjeli, Constantine, Algeria.

Received: 30 December 2020 Accepted: 11 April 2021

Published online: 20 April 2021

\section{References}

Abdallah-Nekache N, Laraba I, Ducos C, Barreau C, Bouznad Z, Boureghda H (2019) Occurrence of fusarium head blight and fusarium crown rot in Algerian wheat: identification of associated species and assessment of aggressiveness. Eur J Plant Pathol 154(3):499-512. https://doi.org/10.1007/s1 0658-019-01673-7

Abd-Elsalam KA, Almohimeed I, Moslem MA, Bahkali AH (2010) M13-microsatellite PCR and rDNA sequence markers for identification of Trichoderma (Hypocreaceae) species in Saudi Arabian soil. Genet Mol Res 9:2016-2024. https://doi.org/10.4238/vol9-4gmr908

Akrami M, Yousefi Z (2015) Biological control of Fusarium wilt of tomato (Solanum lycopersicum) by Trichoderma spp. as Antagonist fungi. Biol Forum 7:887-892

Ann J, Cynthia C, Federico G, Lani L (2017) In vitro Evaluation of the Antagonistic Activity of Trichoderma sp. against Fusarium verticillioides. Int J Agric Technol 13(7.3):2539-2548 
Asad SI, Shamim A, Iftikhar A (2009) Characterization of Bipolaris sorokiniana isolated from different agro-ecological zones of wheat production in Pakistan. Pak J Bot 41(1):301-308

Behzad H, Mousa T, Mohammad R, Mahdi D (2008) Biological potantial of some Iranian Trichoderma isolates in the control of soil borne plant pathogenic fungi. Afr J Biotechnol 7(8):967-972 17

Benttoumi N, Colagiero M, Sellami S, Boureghda H, Keddad A, Ciancio A (2020) Diversity of Nematode Microbial Antagonists from Algeria Shows Occurrence of Nematotoxic Trichoderma spp. Plants. 9(8):941. https://doi.org/10.3390/pla nts9080941

Carbone I, Kohn LM (1999) A method for designing primer sets for speciation studies in filamentous ascomycetes. Mycologia 91(3):553-556. https://doi. org/10.1080/00275514.1999.12061051

Daami-Remadi M, El Mahgjoub (2001) Lutte biologique contre la pourriture aqueuse des tubercules de pomme de terre par Trichoderma harzianum. Ann L'INRAT 74:167-186

Davet P, Rouxel F (1997) Detection et isolation des champignons du sol. INRA, Paris

Dendouga W, Boureghda H, Belhamra M (2016) Biocontrol Of Wheat Fusarium Crown And Root Rot By Trichoderma Spp. And Evaluation Of Their Cell Wall Degrading Enzymes Activities. Acta Phytopathol Entomol Hung 51(1):1-12. https://doi.org/10.1556/038.51.2016.1.1

Dhingra OD, Sinclair JB (1985) Basic plant pathology methods. CRC Press, Inc, Boca Raton, p 355. https://doi.org/10.1201/9781315138138

El-Komy MH, Saleh AA, Eranthodi A, Molan YY (2015) Characterization of Novel Trichoderma asperellum isolates to select effective biocontrol agents against tomato Fusarium Wilt. Plant Pathol J 31(1):50-60. https://doi.org/10.5423/PPJ. OA.09.2014.0087

Erginbas-Orakci G, Poole G, Nicol JM, Paulitz T, Dababat AA, Campbell K (2016) Assessment of inoculation methods to identify resistance to Fusarium crown rot in wheat. J Plant Dis Protect 123(1):19-27. https://doi.org/10.1007/S41348016-0001-8

Ghanbarzadeh B, Safaie N, Goltapeh EM, Danesh YR, Khelghatibana F (2016) Biological control of Fusarium basal rot of onion using Trichoderma harzianum and Glomus mosseae. J Crop Prot 5(3):359-368. https://doi.org/1 0.18869/modares.jcp.5.3.359

Ghazalibiglar H, Hampton JG, Van ZijlldeJong E, Holyoake A (2016) Evaluation of Paenibacillus spp. isolates for the biological control of black rot in Brassica oleracea var. capitata (cabbage). Biocontrol Sci Tech 26:504-515. https://doi. org/10.1080/09583157.2015.1129052

Goodwin DC, Lee SB (1993) Microwave mini prep of total genomic DNA from fungi, plants, protists and animals for PCR. Biotechniques. 15:438-444

Haouhach S, Karkachi N, Oguiba B, Sidaoui A, Chamorro I, Kihal M, Monte E (2020) Three New Reports of Trichoderma in Algeria: T. atrobrunneum, (South) T. longibrachiatum (South), and T. afroharzianum (Northwest). Microorganisms 8(10):1455. https://doi.org/10.3390/microorganisms8101455

Harman GE, Howell CR, Viterbo A, Chet I, Lorito M (2004) Trichoderma species opportunistic, avirulent plant symbionts. Nat Rev Microbiol 2(1):43-56. https://doi.org/10.1038/nrmicro797

Harman GE, Kubicek CP (eds) (1998) Trichoderma and Gliocladium (Vol 2). Taylor and Francis Ltd, UK. https://doi.org/10.1201/9781482267945

Hibar K, Daami-Remadi M, Khiareddine H, El Mahjoub M (2004) Effet inhibiteur in vitro et in vivo du Trichoderma harzianum sur Fusarium oxysporum f. sp. radicislycopersici. Biotechnol Agron Soc Environ 2005 9(3):163-171

Hmouni A, Hajlaoui MR, Mlaiki A (1996) Résistance de Botrytiscinerea aux benzimidazoles et aux dicarboximides dans les cultures abritées de tomate en Tunisie. OEPP/EPPO Bull 26(3-4):697-705. https://doi.org/10.1111/j.13 65-2338.1996.tb01513.x

Khan MR, Fischer S, Egan D, Doohan FM (2006) Biological Control of Fusarium Seedling Blight Disease of Wheat and Barley. Phytopathol. 96(4):386-394. https://doi.org/10.1094/phyto-96-0386

Khandelwal M, Datta S, Mehta J, Naruka R, Makhijani K, Sharma G, Kumar R, Chandra S (2012) Isolation, characterization and biomass production of Trichoderma viride using various agro products-A biocontrol agent. Adv Appl Sci Res 3:3950-3955

Laraba I, Boureghda H, Abdallah N, Bouaicha O, Obanor F, Moretti A, O'Donnell K (2017) Population genetic structure and mycotoxin potential of the wheat crown rot and head blight pathogen Fusarium culmorum in Algeria. Fungal Genet Biol 103:34-41. https://doi.org/10.1016/j.fgb.2017.04.001

Lu Z, Tu G, Zhang T, Li Y, Wang X, Zhang Q, Song W, Chen J (2020) Screening of antagonistic Trichoderma strains and their application for controlling stalk rot in maize. J Integr Agric 19(1):145-152. https://doi.org/10.1016/S2095-3119(19)62734-6
Mahmoud AF (2016) Genetic Variation and Biological Control of Fusarium graminearum Isolated from Wheat in Assiut-Egypt. Plant Pathol J 32(2):145156. https://doi.org/10.5423/ppj.oa.09.2015.0201

Matarese F, Sarrocco S, Gruber S, Seidl-Seiboth V, Vannacci G (2011) Biocontrol of Fusarium head blight: interactions between Trichoderma and mycotoxigenic Fusarium. Microbiol. 158(1):98-106. https://doi.org/10.1099/mic.0.052639-0

McKinney HH (1923) Influence of soil temperature and moisture on infection of wheat seedlings by Helminthosporium sativum. J Agric Res 26:195-217

Mielniczuk E, Skwaryło-Bednarz B (2020) Fusarium Head Blight, Mycotoxins and Strategies for Their Reduction. Agron 10(4):509. https://doi.org/10.3390/agronomy10040509

Moya-Elizondo EA (2013) Fusarium crown rot disease: biology, interactions, management and function as a possible sensor of global climate change. Cienc Investig Agrar 40(2):235-252. https://doi.org/10.4067/s0718-16202013000200001

Mukhopadhyay AN (2005) Trichoderma-Promises and pitfalls. J Mycol Plant Pathol 35:533-534

Saharan MS, Sharma AK, Singh S (2008) Management of head scab (Fusarium spp.) of wheat (Triticum aestivum) with bioagents. Indian J Agric Sci 78(4):328-332

Siou D, Gélisse S, Laval V, Elbelt S, Repinçay C, Bourdat-Deschamps M, Suffert F, Lannou C (2015) Interactions between head blight pathogens: consequences for disease development and toxin production in wheat spikes. Appl Environ Microbiol 81(3):957-965. https://doi.org/10.1128/AEM.02879-14

Siou D, Gélisse S, Laval V, Repinçay C, Canalès R, Suffert F, Lannou C (2013) Effect of wheat spike infection timing on fusarium head blight development and mycotoxin accumulation. Plant Pathol 63(2):390-399. https://doi.org/10.1111/ppa.12106

Srivastava RK, Singh RK, Kumar N, Singh S (2010) Management of macrophomina disease complex in jute (Corchorus olitorius) by Trichoderma viride. J Biol Control 24:77-79. https://doi.org/10.18311/JBC/2010/3578

Stein JM, Osborne LE, Bondalapati KD, Glover KD, Nelson CA (2009) Fusarium head blight severity and deoxynivalenol concentration in wheat in response to Gibberella zeae inoculum concentration. Phytopathol 99(6):759-764. https://doi.org/10.1094/phyto-99-6-0759

Stoppacher N, Kluger B, Zeilinger S, Krska R, Schuhmacher R (2010) Identification and profiling of volatile metabolites of the biocontrol fungus Trichoderma atroviride by HS-SPME-GC-MS. J Microbiol Methods 81(2):187-193. https://doi. org/10.1016/j.mimet.2010.03.011

Tian Y, Tan Y, Liu N, Liao Y, Sun C, Wang S, Wu A (2016) Functional Agents to Biologically Control Deoxynivalenol Contamination in Cereal Grains. Front Microbiol 7. https://doi.org/10.3389/fmicb.2016.00395

Tsegaye Redda E, Ma J, Mei J, Li M, Wu B, Jiang X (2018) Antagonistic potential of different isolates of Trichoderma against Fusarium oxysporum, Rhizoctonia solani, and Botrytis cinerea. Eur J Exp Biol 08:212. https://doi.org/10.21767/224 8-9215.100053

Wegulo SN, Baenziger PS, Hernandez Nopsa J, Bockus WW, Hallen-Adams H (2015) Management of Fusarium head blight of wheat and barley. Crop Prot 73:100-107. https://doi.org/10.1016/j.cropro.2015.02.025

White TJ, Bruns T, Lee S, Taylor J (1990) Amplification and direct sequencing of fungal ribosomal RNA genes for phylogenetics. In: Innis MA, Gelfand DH, Sninsky JJ, White TJ (eds) PCR Protocols: a guide to methods and applications. Academic Press, San Diego, pp 315-322. https://doi.org/10.101 6/b978-0-12-372180-8.50042-1

Xu X, Nicholson P (2009) Community ecology of fungal pathogens causing wheat head blight. Annu Rev Phytopathol 47(1):83-103. https://doi.org/1 0.1146/annurev-phyto-080508-081737

Zeilinger S, Gruber S, Bansal R, Mukherjee PK (2016) Secondary metabolism in Trichoderma - Chemistry meets genomics. Fungal Biol Rev 30(2):74-90. https://doi.org/10.1016/j.fbr.2016.05.001

\section{Publisher's Note}

Springer Nature remains neutral with regard to jurisdictional claims in published maps and institutional affiliations. 